\title{
Factors affecting flood insurance purchase in residential properties in Johor, Malaysia
}

\author{
U. G. Aliagha, T. E. Jin, W. W. Choong, M. Nadzri Jaafar, and H. M. Ali \\ Department of Real Estate, Faculty of Geoinformation and Real Estate, Universiti Teknologi Malaysia, Malaysia \\ Correspondence to: U. G. Aliagha (galiagha@yahoo.com.sg)
}

Received: 25 January 2014 - Published in Nat. Hazards Earth Syst. Sci. Discuss.: 30 April 2014

Revised: 7 November 2014 - Accepted: 13 November 2014 - Published: 17 December 2014

\begin{abstract}
High-impact floods have become a virtually annual experience in Malaysia, yet flood insurance has remained a grossly neglected part of comprehensive integrated flood risk management. Using discriminant analysis, this study seeks to identify the demand-side variables that best predict flood insurance purchase and risk aversion between two groups of residential homeowners in three districts of Johor State, Malaysia: those who purchased flood insurance and those who did not. Our results revealed an overall $34 \%$ purchase rate, with Kota Tinggi district having the highest (44\%) and thus the highest degree of flood risk aversion. The Wilks' lambda $F$ test for equality of group means, standardised discriminant function coefficients, structure correlation, and canonical correlation has clearly shown that there are strong significant attribute differences between the two groups of homeowners, based on the measures of objective flood risk exposure, subjective risk perception, and socioeconomic cum demographic variables. However, the measures of subjective risk perception were found to be more predictive of flood insurance purchase and flood risk aversion.
\end{abstract}

\section{Introduction}

Flooding disasters are Malaysia's worst nightmare in terms of the overall area and population affected, frequency, financial loss, and psychological trauma. The real estate sector is hit particularly hard. Historical records show that Malaysia has experienced major flood events in 1886, 1926, 1931, 1947, 1954, 1957, 1965, 1967, 1970, 1971, 1988, 1993, 1996, 2000, 2006, 2007, 2008, 2009, 2010, 2011, and 2013. It is estimated that the average annual flood damage in
Malaysia is about RM3 billion (USD 912.8 million) (Deloitte, 2003), which can negatively affect the nation's GDP. Records also show that the trend has been increasing. This is glaringly obvious when one compares the two worst flood events in the country: the 1971 flood cost RM 200 million (USD 60.8 million) and resulted in the death of 61 persons; the successive 50 and $100 \mathrm{yr}$ floods hit Johor State in December 2006 and January 2007 and together cost RM 1.5 billion (USD 456.4 million) and led to the deaths of 18 persons (MNREM, 2007; Badrul et al., 2010; Hamzah et al., 2012).

Threats of flooding to Malaysia's coastal real estate could be enormous when one realises that Peninsular Malaysia has $29000 \mathrm{~km}^{2}$ total land area prone to flooding, thus putting 4.82 million people at risk (Liu and Chan, 2003; Hasan and Minirah, 2013). This is compounded by the increasing urbanisation and mounting evidence that climate change will exacerbate the flood risk (IPCC, 2007; Stern, 2006, 2008; Bubeck et al., 2012). Keizrul Abdullah, Director-General of Drainage and Irrigation Department, has warned that as Malaysia approaches 2020 it should expect a serious flood management challenge owing to an increased severity and frequency of floods. In addition, the largest threat to the entire corridor area may be the exposure of Malaysia's 189 river basins to climate change (MNREM, 2007; BERNAMA, 2007). Pundits have warned that property owners in a high-risk area should expect premiums to double in the coming years as insurance firms operating in these areas experience cost-ofcoverage rise of as much as $100 \%$ in the next 10 years (Gerrit, 2009). Some insurance companies in Malaysia have already started reporting flood insurance claims from affected policy holders. It was also estimated that the December and January 2007 floods cost insurance firms in Malaysia about RM 100 million (USD 30.4 million). Yet the claims repre- 
sented only $7 \%$ of the total damage compared to the RM 1.5 billion cost to the government (Singh, 2007). The reason for low insurance claims from floods may lie in the fact that flood insurance penetration rate in Malaysia is very low, about $5 \%$ (Business Times, 5 March 2007), even though there are huge business opportunities for flood insurance. In contrast to the insurance industry, the government is paying massive amounts for flood relief damages.

An argument for enhanced flood insurance penetration as an integral part of a comprehensive flood risk management in Malaysia could be established. Under the auspices of the Public Works and Irrigation Department, the government has over the years taken some significant structural and non-structural measures to address flood problems. Amongst structural measures are channel enlargement, construction of levees and embankments, flood bypasses, river diversions, poldering, and construction of flood storage dams and flood attenuation ponds. Non-structural measures include restriction of development along costal corridors, land use zoning, resettlement of population, flood proofing, flood forecasting, and warning systems. Despite these laudable measures, the incidents of floods and attendant losses continue to increase. The main reasons are fourfold: (1) the Public Works and Irrigation Department has not or may not be able to protect all areas or control all floods; (2) due to increasing urbanisation, private construction continued in flood-prone areas (Chan, 1997); (3) based on observed records, the effect of climate change on frequency and intensity of rainfall has become an accepted reality; (4) even where structural measures are in place there is always the probability of residual flood, which Plate (2002) and Merz (2006) described as the remaining part of the risk after implementing a protection system. Put differently, residual risk is the portion of risk that remains after flood control structures have been built. In essence, there is always the possibility of a flood event greater than the design capacity of levees or embankments, which may result in breaching or overtopping of the defences and flooding of adjacent properties. As Kreibich et al. (2005) pointed out, absolute flood protection is impossible.

In the US, UK and recently in Australia after the 2011 Brisbane flood, flood insurance has been adopted as a tool for residual flood risk management to support and complement a non-structural approach. As a result, flood insurance has been incorporated as part of a comprehensive integrated flood risk management. However, this is not the case in Malaysia. Flood insurance as a non-structural flood risk management tool is not a common practice in Malaysia as floods are still viewed as an "act of God"; moreover, it is neither a legal requirement to have flood insurance for floodprone properties in Malaysia nor is there any incentive from the government to promote flood insurance as an instrument for flood risk management in the country (Keizrul, 2004; Ho, 2009). Consequently, flood insurance has become a neglected aspect of comprehensive integrated flood risk management in Malaysia. Flood insurance is also profoundly under-researched not only in Malaysia but across Southeast Asia, where collateral damage to properties from floods are frequent phenomena. Even numerous studies in Southeast Asia on flood resilience and adaptations strategies have missed out on flood insurance or have paid it only cursory attention. Though flood insurance cannot prevent actual property damages or loss of life as structural measures would do, it can significantly reduce the economic risk associated with flooding. An insured property damaged by flood can be replaced quickly without much financial stress to the government. A community with extensive flood insurance can rebuild faster after a flood. Kunreuther and Roth Sr. (1998) described flood insurance as serving the purpose of reducing the economic impact of individual losses by arranging for the transfer of all or part of the loss to others who share the same risk. Similarly, Bubeck et al. (2012) conceive flood insurance as a private mitigation measure which reduces financial consequences for an individual once a flood occurs. The demand for insurance is driven by an individual's knowledge of potential risk, who opts to transfer the risk to an insurance company that is in a better position to effectively absorb and diversify the risk. Hence, buying flood insurance is regarded as one of the precautionary risk reduction measures taken with flood-exposed buildings (Kreibich et al., 2011).

Residential flood insurance purchase requires both demand and supply sides. The demand side is determined by the households, while the supply side is mainly controlled by the insurance firms. Our study focuses on the demand-side aspect of residential flood insurance and thus aims to: (1) determine the factors that influence flood insurance purchase decisions and the degree of flood risk aversion among residential homeowners in three districts of Johor State; (2) determine if there are significant attribute differences in the degree of risk aversion between two groups of residential homeowners: those who purchased flood insurance and those who did not; and (3) determine the most important variables that best differentiate and account for the degree of risk aversion between the group of homeowners that purchased flood insurance and the group that did not.

\section{Review of related theories and literature}

\subsection{Prospect theory under flood insurance risk decisions}

Two popular theories used to explain decision-making under risk or uncertainty are the expected utility (EU) theory and the prospect theory (PT). EU is the standard and rational theory of decision-making under risk that relies on a linear composite of weighted probability outcomes to compute EU. It is founded on the principle of diminishing marginal utility and uses net wealth as the only reference point (Chateauneuf and Cohen, 1994; Rabin, 1997, 2000a; Kunreuther and Pauly, 2005; Desrosiers, 2012). In regards to insurance decision- 
making, EU theory holds that people will purchase full insurance only if the premiums are fair to a point where premiums are equal to expected losses (Kunreuther and Pauly, 2006a; Ulrich, 2012). In the scenario of EU theory, demand for flood insurance for a risk-averse person will be based only on the offer of an actuarially fair premium that reflects full coverage, where benefits from the premium equal the expected losses. Under this condition, the individual with insurance coverage is not bothered whether there is flood or not. This is because whether the flood disaster occurs or not, the utility from coverage will remain the same. Perhaps that is why Kunreuther and Pauly (2005) theorised that EU theory has a constant absolute risk-aversion utility function.

Owing to the fact that EU is a rational theory that operates on the assumptions of context invariance, availability of full formation, and complete knowledge of all possible outcomes, it always predicts accurate probabilities of outcomes and consistently selects the best payoff among alternatives using linear probability weighting (Sebora, 1995; Isenberg, 1989; March and Shapira, 1987). However, it has been widely criticised for a lack of explanatory power (Rabin, 2000a; Kunreuther and Pauly 2005; Sydnor, 2010; U1rich, 2012). Moreover, Rabin (2000a) argues that if the only reason people are risk averse is the diminishing marginal utility of wealth-which is the only explanation for risk aversion in EU theory-then they should be very close to riskneutral in modestly sized risks. Or as Desrosiers (2012) contends, EU theory, with its associated decreasing marginal utility of wealth, cannot provide a plausible explanation for why individuals purchase moderate- or small-scale insurance. Levin (2006) conceived that one of the limitations of EU theory is that it treats uncertainty as objective risk, where the probabilities are objectively known or at best serve as subjective maps of the objective values of possible outcomes (Sebora, 1995). However, predicting insurance purchases based purely on objective measures may be misleading as perception of risk is often subjective (Kunreuther, 1978; Slovic, 1987).

PT was developed by Kahneman and Tversky (1979) and later examined and quantified further by Tversky and Kahneman (1981, 1992). PT argues that because of complexities in decision-making, limited information, and analytical ability, preferences are often not consistent and an individual often does not use linear probability weights to determine values. Rather, PT contends that context and subjective values influence decisions under uncertainty. As a result, decision makers may not select the alternative with the highest payoff and may not use net wealth as the reference point as depicted in EU theory. Empirical evidence suggests that people often make decisions by comparing changes in their financial status with reference to specific actions rather than the impact of the actions on final wealth utility function (Kaheman and Tversky, 1979; Tversky and Kahneman, 1992; Kunreuther and Pauly, 2005). Leaning more on subjective influence measures, Slovic (1987) and Botzen et al. (2009) pointed out that people commonly evaluate and make risk decisions not only on the basis of objective risk exposure but also from the perspective of risk perceptions involving intuitive risk judgments or risk beliefs.

Moreover, PT postulates that people, including modestrisk individuals, are willing to take an additional risk by paying more in order to avoid loss. In support of this postulation, studies by Pashigian et al. (1966), Drèze (1981), Cutler and Zeckhauser (2004), Kunreuther and Pauly (2006a), Sydnor (2010), and Ulrich (2012) reveal evidence that modestrisk people often buy insurance policies with premiums significantly exceeding expected losses. PT explains this with the concept of "loss aversion" and how people weigh probabilities of outcome. In weighing the probabilities of outcomes, people often overvalue small probabilities and undervalue larger probabilities (Rabin, 2000b; Sydnor, 2010). This is because there is evidence that people are more sensitive to small gains/losses compared to larger ones (Kahneman and Tversky, 1979; Hershey and Schoemaker, 1980). In the parlance of PT, this tendency for people to weigh losses more heavily than gains is called "loss aversion." Under this notion, Rabin (2000b) and Sydnor (2010) pointed out that the decision to take up insurance is determined in the loss domain. PT encourages people to take actions to avoid losses and maximize gain (Eckles and Volkman Wise, 2011). Against this notion, Eckles and Volkman (2011) argue that, in line with PT, people will "make insurance decisions in order to minimize the domain where a loss is experienced and maximize the domain where a gain is experienced."

This study primarily supports PT, thus acknowledging that the decision to purchase flood insurance will most likely be motivated by gains and losses as well as agreeing that both objective risk exposure and risk perceptions influence insurance purchase decisions. The study also supports PT postulation that people, including modest-risk individuals, are willing to take an additional risk by paying a more-than-fair premium in order to avoid loss. Though Malaysians living in flood-prone areas may rationally prefer the actuarially fair premium, some people, particularly those motivated by loss aversion, may realistically be willing to pay slightly more than the fair price to avoid expected loss (ceteris paribus).

\subsection{Literature review}

A risk-averse homeowner would be more likely to purchase a flood insurance policy (Kriesel and Landry, 2004; Smith, 1968). As Botzen et al. (2009) contend, actual purchase of insurance by an individual is a good indicator of risk aversion since it reveals a preference for financial protection. Purchasing flood insurance is, however, contingent upon the degree of objective exposure and susceptibility of the property to flood, the homeowner's perception of risk, and the socio-economic cum demographic traits of the homeowner. Numerous studies have highlighted the specific variables that 
underlie these three factors that could influence the decision to purchase flood insurance to protect against the risk.

\subsubsection{Objective exposure and susceptibility}

A house location's elevation may well determine susceptibility or sensitivity to flood. As such, the elevation of a building has been observed to be one of the factors underlying a homeowner's perceived probability of losses. Homeowners whose buildings are on elevated ground are less likely to purchase insurance. Dixon et al. (2006) also found out that the probability of people purchasing flood insurance is considerably higher in a coastal flooding area than at high elevation or in non-coastal areas.

Also, the proximity to large bodies of water exposes homes to flooding. Botzen et al. (2009) found that houses near a river are more likely to suffer flood damage than houses far away from a river once a dike breaches or is overtopped by high water levels. As Dixon et al. (2006) posit, proximity to large bodies of water that are subject to coastal flooding serves as a constant reminder to homeowners in the community of the flood risk they face. From their research, Dixon et al. (2006) found out that a location with a higher number of properties at risk of being flooded (known as a special flood hazard area) has a higher demand for flood insurance. This argument is further supported by Kriesel and Landry's (2004) findings that property owners near a flood zone are more likely to purchase flood insurance. Their research shows that an increase of $1 \%$ in distance from the flood zone decreases the probability of purchasing flood insurance by $0.88 \%$.

\subsubsection{Subjective perception of risks}

Baumann and Sims (1978) found evidence that past experience with disasters motivates insurance adoption. They found higher insurance uptake among homeowners who had suffered previous damage from a flood. When estimating or predicting the probability of flood, human beings tend not to worry too much until they have experienced a distasteful event, at which time they will learn from the event and better prepare for the next occurrence (Kunreuther, 1978; Kunreuther et al., 1978; Epple and Lave, 1988; Kunreuther and White, 1994). According to Burton and Kates (1964), the rare and unpredictable occurrences of disasters make individuals more unlikely to undertake any flood mitigation or prevention. Dixon et al. (2006) found that flood experience serves as a reminder of flood damages and thus results in a higher flood insurance policy subscription rate among property owners. Equally, the time of the last flood has been observed to have an influence on the decision of a homeowner to purchase insurance. Not experiencing flood damage for several years has led to a decline in renewal rate for policies in comparison to other types of insurance coverage (Kunreuther and White, 1994; Palm, 1981). This means, in essence, that the low probability of flood occurrence makes homeowners think that it is not all that necessary to renew their flood insurance policy since a flood is something that does not occur frequently. Structural flood control measures, such as dykes, levees, floodwalls, reservoirs, and bypass channels are traditionally used to reduce susceptibility, and as such perception of vulnerability increases when they are not provided. The effect of this should be an increase in the subscription to flood insurance. Ironically, the opposite is often the case where they are provided. Levees create a false sense of security among coastal residents who believe that they are fully protected against future disasters and therefore feel no need to take flood insurance (WMO, 2006; Kunreuther and Pauly, 2006b). Lack of knowledge and awareness as well as the failure of local authorities to seek eligibility for the coverage to their communities has been blamed for the low penetration rate of flood insurance (Browne and Hoyt, 2000). Browne and Hoyt added that increasing information seeded into the public's awareness of the danger posed by the flood may increase the penetration of flood insurance.

\subsubsection{Socio-economic and demographic determinants}

Homeowners feel reluctant to insure their property due to premium and budget constraints. The decision to purchase a flood insurance policy is dependent on a certain level of income of the property owner. When one's income is not even enough to meet one's immediate needs, purchasing flood insuring policy will not be included in the budget. Smith (1968) noted in his model that people will forgo flood insurance if the premium price for flood insurance is higher than the probability of total loss from a flood. In their own view, Browne and Hoyt (2000) noted that a decrease in the price charged for flood insurance policy would eventually increase the probability of purchasing flood insurance. Kriesel and Landry (2004) added that the wealth of a homeowner may also influence the decision to purchase a flood insurance policy: a homeowner with a higher income is more likely to purchase flood insurance, and a higher income may lead to a higher penetration rate. According to a research study conducted by FEMA (1997), homeowners who have not purchased flood insurance felt that they could not afford the premium for flood insurance. Also, it is hard to convince property owners to allocate a significant part of their income to purchase flood insurance when losses have low probability and are likely to be less than the subscription coverage. Hence, homeowners feel that the expenditure on insurance is a poor investment (Baumann and Sims, 1978; Johnson, 1978; Kunreuther et al., 1978; Palm, 1981). Lamond et al. (2009) observed that homeowners might choose not to purchase flood coverage because they expect that, in the long term, the cost of damages from flood will be lower than the sum of annual premiums. In contrast, Blanchard-Boehm et al. (2001) found that those who have purchased flood insur- 
ance felt that the insurance will be able to cover the cost of damages.

\section{Data and method}

\subsection{Data}

The data used in this study were based on a stratified random survey of residential homeowners in three districts of Johor State, namely Kota Tinggi, Segamat, and Johor Bahru. A total of 315 sets of questionnaires were distributed among the homeowners in each district. Only 235 were received while 80 were not returned. Out of the 235 received, 28 were rejected because of incomplete responses. The remaining 207 were used for the analysis.

\subsection{Instrument and measures}

The questionnaire was designed to tap into homeowners' responses to measures of objective risk exposure, subjective risk perception, and socio-economic cum demographic variables that could determine their likelihood of purchasing flood insurance and thus influence their flood risk aversion orientation. Two variables were used to elicit measures of objective flood risk exposure: (1) the distance from a floodprone river and (2) a house location's elevation of property. The two variables were measured on an interval scale. For subjective risk perception, the measures are: (1) number of high-impact floods experienced; (2) expectation of an increase in future flood frequency; (3) likelihood of dropping flood insurance if a flood is not experienced for 2 years; (4) perception that flood insurance premiums are high but willingness to pay slightly more than the fair price; (5) perception of unreliability of insurance firms to pay insurance claims and their reluctance to provide flood insurance coverage; and (6) perception that the flood protection system is not adequate.

The items were selected to measure subjective risk perception because they reflect subjective risk judgements and values, and there is literature in support of them. For example, item (3) ("likelihood of dropping flood insurance if flood is not experienced for 2 year") reflects the respondents' perceived judgements of the immediacy of the flood and its effect. That is the extent to which the homeowners perceive the risk of flooding to be reoccurring in the immediate future affect their decision to renew or purchase flood insurance. In our literature it was noted that the time of the last flood has been observed to have an influence on the decision of a homeowner to purchase insurance. Not experiencing flood damage for several years has led to a decline in the renewal rate for policies in comparison to other types of insurance coverage (Kunreuther and White, 1994; Palm 1991). Similarly, item (4) ("perception that flood insurance premiums are high but willingness to pay slightly more than the fair price") proves that the subjective risk judgements and values of modest-risk individuals go beyond the linear standard rationality that prefers an actuarially fair premium to show a more realistic world situation by accepting a premium slightly more expensive than the fair price. This was supported by PT, which postulates that people, including modest-risk individuals, are willing to take an additional risk by paying more in order to avoid loss. In support of this postulation, studies by Pashigian et al. (1966), Drèze (1981), Cutler and Zeckhauser (2004), Kunreuther and Pauly (2006a), Sydnor (2010), and Ulrich (2012) reveal evidence of modest-risk people often buying insurance policy with premiums significantly exceeding expected losses.

In the same vein, items (5) and (6) reflect subjective risk judgements. For example, item (6) ("perception that the flood protection system is not adequate") reflects how the respondents perceive the existing structural flood control measures, such as dykes, levees, and floodwalls.

Except for question 1, all the questions tapping into subjective risk perception contained statements that were designed to elicit the respondent's level of agreement using a 5point Likert scale ( 1 being strongly disagree, 5 being strongly agree). Socio-economic cum demographic variables were assessed using: (1) income level, (2) education level, (3) gender, (4) race, and (5) age. Questions 1 and 5 were measured on an interval scale, question 2 was on a rank scale, and questions 3 and 4 were on a nominal scale.

The study attempted to discover if there were significant differences between those who purchased flood insurance and those who did not, using the discriminant analysis method. To this end, the dependent grouping variable ("do you have flood insurance?") is a dichotomous variable measured nominally as 1 being "yes, I have flood insurance" or 2 being "no, I do not have flood insurance". The variable was also used to classify the homeowners by whether they were risk averse or not. As pointed out earlier, Botzen et al. (2009) contend that the purchase of insurance by a person is a good indicator of risk aversion because it represents a revealed preference for financial protection. This is even more applicable in Malaysia, where flood insurance is voluntary.

\subsection{Participants}

The research participants were selected based on a two-stage stratified sampling scheme involving primary and secondary sampling units in each of the districts. Based on this design, the 315 samples were selected from an estimated 45000 owner-occupied residential houses within $7 \mathrm{~km}$ of a major river flood plain in each district. The questionnaires were administered face-to-face to homeowners aged 21 years and older. However, the respondents who had no time to complete the questionnaire either immediately or after the second appointment were given self-addressed stamped envelopes to return the questionnaires.

Out of the 207 usable questionnaires received, $44 \%$ were from Kota Tinggi $(N=91)$, where $48 \%$ (44) of them were 
male and $55 \%$ (47) were female. $26.6 \%$ (55) were from Segamat, where $44 \%$ (24) of them were male and $56 \%$ (31) were female. $29 \%$ (61) were from Johor Bahru, where $46 \%$ (28) and $54 \%$ (33) of them were male and female respectively. In other words, out of the 207 respondents, $46 \%$ (95) of them were male and $54 \%$ (112) were female. In terms of race, $37 \%$ of the respondents were Malays $(N=76), 52 \%$ Chinese $(N=108)$, and $11 \%$ Indians $(N=22)$. In terms of age profile, the pattern of response from the highest order was $29.5 \%$ (61) between the ages of 31 and $50 ; 25 \%$ (52) between the ages of 21 and 30; $23 \%$ (47) between the ages of 31 and 40;15\% (31) between the ages of 51 and 60; and $7.7 \%$ (16) above the age of 60 . Even though the Malay received the highest number of distributed questionnaires, the response rate was higher among the Chinese. This is not what we expected as the population distributions in the regions are in $67 \%$ Malays, $25 \%$ Chinese, and $7 \%$ Indians. Nevertheless, the total number of usable samples received was large enough to carry out a discriminant analysis.

\subsection{Method}

Discriminant analysis was adopted as the analytical statistic for this study. The rationale for its use lies in the fact that the study involved testing group mean differences between two groups of respondents: those who did and did not purchase flood insurance based on a set of predictive variables. A major advantage of the discriminant analysis is that it has the capacity to analyse simultaneously two classes of means and standard deviations of groups of samples or respondents. The first class is the total mean score and standard deviation of all the respondents of each variable. The second class is the group mean score and standard deviations of subclasses of respondents on the same variable. If the analysis involves two groups of sample populations it is known as two-group discriminant analysis. If it involves three groups of sample populations it is known as three-group discriminant analysis. In the case of this study, there are two groups of respondents: those who purchased flood insurance (72) and those who did not (135). Consequently, a two-group discriminant analysis was adopted.

Discriminant analysis is an appropriate statistical technique for testing for equality of group means and building a predictive model of group membership based on a set of observed discriminating variables (Hair al., 1987). This allows for a linear combination of two or more discriminant variables that best differentiate between the groups. The relationship is expressed as the ratio of between-group to withingroup variances. The linear combination is derived from the following equation:

$Z=W_{1} X_{1}+W_{2} X_{2}+W_{3} X_{3} \ldots+W_{n} X_{n}$,

where $Z$ is the discriminant score, $W$ is the discriminant weights (discriminant coefficients), and $X$ is the independent discriminating variables.
Discriminant analysis provides descriptive statistics (total mean and group mean) and inferential statistics identifying and analysing group differences. Inferential statistics include the $F$ test for Wilks' lambda, Wilks' lambda model, standardized canonical discriminant function (SDFC), eigenvalues, canonical correlation, and functions at group centroids. The lambda varies from 0 to 1 : closer to 0 implies group means differ and closer to 1 implies less group means difference. ANOVA $(F)$ for Wilks' lambda tests if there are significant group mean differences. In other words, the $F$ test for Wilks' lambda provides useful statistics to identify variables that make significant differentiation between or among groups. The standardized discriminant function coefficients were used to assess each variable's unique contribution to discriminant function. A low standardized coefficient implies that the groups did not differ much on that variable. The canonical correlation depicts the multiple correlations between the predictors and the discriminant function.

The structure matrix coefficient shows the correlation between each predictor variable and the discriminant function. Correlations that have loadings $\geq 0.3$ are considered significant and therefore have practical significance (Hair et al., 1998; Ndubisi, 2011). In group mean difference analysis, discriminant analysis has an advantage over the $t$ test because it compares the groups in terms of group centroids, thus taking into account the interactions between the individual variables (Ndubisi, 2008). A necessary major condition for application of discriminant analysis is meeting the assumption that the variance-covariance matrices are equivalent for the groups. This is often verified by Box's $M$ test of the null hypothesis that the covariance matrices do not differ between groups. In our study, the result shows similar log determinants and variances that are not significantly different (Box's $M=16.725$, $F=1.108 ; p$ value $(0.312)$ is greater than 0.05$)$. Thus the hypothesis that the groups do not differ is accepted, implying that it is appropriate to apply discriminant analysis.

\section{Results and discussion}

Concerning the flood insurance purchase rate, our results revealed that out of the 207 respondents sampled in the study, only $34 \%$ (72) insured their property against flood while the rest $(66 \%$ or 135$)$ did not. This also implies that $34 \%$ homeowners who purchased flood insurance could be described as more risk averse, ceteris paribus, than the $66 \%$ that did not. The flood insurance subscription rate could be considered somewhat low and below average. The breakdown of flood insurance subscription amongst the three districts showed that Kota Tinggi had the highest rate $(48.3 \%)$, followed by Segamat (40\%) and Johor Bahru (8.2\%). In other words, homeowners in Kota Tinggi and Segamat are more risk averse than those in Johor Bahru in terms of flood insurance. This is not unexpected because the incidence and severity of floods are higher in Kota Tinggi and Segamat. Table 1 
Table 1. Group mean differences and tests of equality of group means.

\begin{tabular}{|c|c|c|c|c|c|c|c|}
\hline \multirow[t]{2}{*}{ Variables } & \multicolumn{3}{|c|}{ Group means } & \multicolumn{4}{|c|}{$\begin{array}{c}\text { Tests of } \\
\text { equality of group means }\end{array}$} \\
\hline & $\begin{array}{r}\text { Total } \\
\text { means }\end{array}$ & $\begin{array}{r}\text { [1] Has } \\
\text { flood } \\
\text { insurance }\end{array}$ & $\begin{array}{r}\text { [2] Has no } \\
\text { flood } \\
\text { insurance }\end{array}$ & $\begin{array}{r}\text { Mean } \\
\text { diff. }\end{array}$ & $\begin{array}{l}\text { Wilks' } \\
\text { lambda }\end{array}$ & $F^{\mathrm{a}}$ & Sig. \\
\hline $\begin{array}{l}\text { Number of high-impact floods experienced } \\
\text { (V-NUMEXP) }\end{array}$ & $2.57(1.32)$ & $3.23(0.97)$ & $2.22(1.35)$ & 1.00 & 0.870 & 30.767 & 0.000 \\
\hline Distance from flood-prone river (V-DISTFD) & $2.09(1.51)$ & $1.38(0.87)$ & $2.46(1.64)$ & 1.08 & 0.885 & 26.564 & 0.000 \\
\hline $\begin{array}{l}\text { Elevation of property } \\
\text { (V-ELEVTN) }\end{array}$ & $1.44(0.49)$ & $1.32(0.47)$ & $1.49(0.50)$ & 0.17 & 0.974 & 4.178 & 0.048 \\
\hline $\begin{array}{l}\text { Perception of high flood insurance premiums but } \\
\text { willing to pay slightly more than the fair price to } \\
\text { insure house } \\
\text { (V-FLPREM) }\end{array}$ & $2.57(1.32)$ & $3.23(0.97)$ & $2.22(1.35)$ & -1.00 & 0.870 & 30.767 & 0.000 \\
\hline $\begin{array}{l}\text { Expect flood frequency to increase in future } \\
\text { (V-EXPFRQ) }\end{array}$ & $3.19(1.18)$ & $3.18(1.21)$ & $3.19(1.17)$ & 0.01 & 1.000 & 0.002 & 0.963 \\
\hline $\begin{array}{l}\text { Perception of unreliability of insurance firms to } \\
\text { pay insurance claims as well as their reluctance to } \\
\text { provide flood insurance coverage (V-INSREL) }\end{array}$ & $3.21(1.10)$ & $2.92(1.22)$ & $3.36(1.01)$ & 0.44 & 0.963 & 7.856 & 0.006 \\
\hline $\begin{array}{l}\text { Perception that a flood insurance premium is high; } \\
\text { not willing to pay slightly higher than fair price } \\
\text { (V-FLPREM) }\end{array}$ & $2.86(0.90)$ & $2.45(0.97)$ & $3.08(0.79)$ & 0.63 & 0.890 & 25.370 & 0.000 \\
\hline $\begin{array}{l}\text { I will drop flood insurance if I do not experience a } \\
\text { flood for } 2 \text { year }\end{array}$ & $2.80(1.13)$ & $2.44(1.27)$ & $2.99(1.00)$ & 0.56 & 0.945 & 11.899 & 0.001 \\
\hline Income level (V-INCOML) & $1.60(0.89)$ & $1.83(1.00)$ & $1.48(0.80)$ & -0.35 & 0.964 & 7.645 & 0.006 \\
\hline Education level (V-EDUCTN) & $1.41(0.78)$ & $1.31(0.62)$ & $1.46(0.84)$ & 0.15 & 0.922 & 1.659 & 0.199 \\
\hline $\begin{array}{l}\text { Flood protection system is not adequate } \\
\text { (V-FLPROT) }\end{array}$ & $3.24(1.22)$ & $3.20(1.29)$ & $3.26(1.19)$ & 0.06 & 0.999 & 0.113 & 0.737 \\
\hline
\end{tabular}

provides group mean scores and tests of equality of group means statistics used to identify variables that make significant differentiation between groups of respondents who purchased flood insurance and those who did not. The column for tests of equality of group means shows that the number of flood experience (NUMEXP) the respondents have had in the past has a strong discriminant power and emerged as the most significant variable $(\lambda=0.870, F=30.767, p<$ 0.001 ) differentiating between the group of respondents who purchased flood insurance and the group of respondents who did not purchase flood insurance. The result shows a very high mean difference of 1.0 between respondents who purchased flood insurance (GROUP1) and those who did not (GROUP2). The mean value for GROUP1 is 3.23 compared to 2.22 for GROUP2.

To further understand the explanation for the differences in group mean, we carried out cross tabulation between flood insurance purchase and flood experience. The results showed that $88 \%$ of respondents who purchased flood insurance had experienced a flood two or more times compared to $42 \%$ of those who did not purchase. Moreover, $46 \%$ of the respondents who did not purchase flood insurance had never ex- perienced a flood, while only $6 \%$ with flood insurance had never experienced flood and $7 \%$ only once. This suggests that there is an interrelationship between flood experience and the tendency to purchase flood insurance. This may be attributed to the fact that an increase in flood experiences translates to a higher subjective risk perception and vulnerability which concomitantly could lead to demand for flood insurance. In essence, the property owners with more flood experience are more likely to purchase flood insurance than those with less experience. However, the fact that $7 \%$ of the homeowners that experienced a flood once and $6 \%$ of those that never experienced a flood actually purchased flood insurance supports PT assertion that moderate- and small-size risk individuals also voluntarily buy insurance. Our findings are consistent with previous studies by McPherson and Saarinen (1977), Kunreuther (1978), Kunreuther et al. (1978), Epple and Lave (1988), and Kunreuther and White (1994) that show the probability of purchasing flood insurance increases with the frequency of flood experience.

The distance of a respondent's property in the study area influenced their willingness to purchase flood insurance. As shown in Table 1, the distance of property from a 
flood-prone river (DISTFD) registered strong discriminatory power and therefore was significant $(\lambda=0.885, F=26.564$, $p<0.001)$ in differentiating between the group of respondents who purchased flood insurance (GROUP1) and the group of respondents who did not purchase flood insurance (GROUP2). The variable shows a very high mean difference of 1.08 between the groups. The mean value for GROUP1 is 1.38 compared to 2.46 for GROUP2. To investigate further the underlying sources of these differences we performed a cross tabulation between the distance of a house from a floodprone river and the purchase of flood insurance. The results revealed that $76 \%$ of respondents who subscribed to flood insurance lived in houses located less than $3 \mathrm{~km}$ from a floodprone river and another $18 \%$ lived within $3-6 \mathrm{~km}$. In contrast, only $46 \%$ of the respondents who did not subscribe to flood insurance lived in houses located less than $3 \mathrm{~km}$ from a flood-prone river. Moreover, $41 \%$ of the people who did not purchase flood insurance lived in houses located more than $6 \mathrm{~km}$ from a river while only $6 \%$ of the respondents who bought flood insurance lived more than $6 \mathrm{~km}$ from a river. What could be deduced from these results is that the nearer a house is located to a flood-prone river, the higher the tendency of the homeowner to subscribe to flood insurance. In other words, proximity to a flood-prone river contributes to the degree of risk averseness such that homeowners located less than $3 \mathrm{~km}$ from a flood-prone river are more risk averse than homeowners located beyond. This result coincides to a great extent with the findings of Kriesel and Landry (2000, 2004) and Landry and Jahan-Parvar (2011) that proximity of a property to a river has a positive effect on flood insurance purchase. Our finding is consistent with previous works by Baumann and Sims (1978), Kunreuther (1978), Dutta et al. (2003), and Dixon et al. (2006) which show that the probability of purchasing flood insurance increases with the frequency of flood experience, flood depth, and lower ground location.

Elevation of their property (ELEVTN) has a weak discriminant power but is still significant $(\lambda=0.974, F=4.178$, $p<0.05$ ) in differentiating between GROUP 1 , who purchased flood insurance, and GROUP 2, who did not purchase flood insurance. While GROUP1 had a lower mean elevation value of 1.32, GROUP2 recorded a higher mean elevation value of 1.49. Moreover, cross tabulation of the house location's elevation with flood insurance purchase shows that $68 \%$ of respondents who purchased flood insurance reside in a low-elevation area while $32 \%$ reside in a high-elevation area. On the other hand, $54 \%$ of the respondents who did not subscribe to flood insurance property live at a low elevation while $46 \%$ reside at a high elevation. These results are expected because a low-elevation location increases physical exposure and vulnerability to floods, which culminates in risk aversion. What these results suggest, therefore, is that the elevation of a property in the study area does affect risk aversion and determines whether the property owner is likely to subscribe to flood insurance. These findings are also in agreement with those of Dixon et al. (2006) and Kriesel and Landry $(2000,2004)$, which hold that higher elevation of property has a positive effect on flood insurance purchase. The results of the tests of the equality of group means for the three variables above (NUMEXP, ELEVTN, DISTFD) provide sufficient evidence to reject the hypothesis of equal group means, and hence we conclude that there is a significant mean difference between the group of respondents who purchase flood insurance and the group of respondents who did not purchase flood insurance in terms of house distance from a flood-prone river, house location's elevation, and amount of flood experience.

The expectation of an increased flood frequency (EXPFRQ) exhibited poor discriminant power and therefore was not significant $(\lambda=0.999, \quad F=0.002, \quad p>0.05)$. Rather, there is more commonality of opinion than difference between groups who have purchased and have not purchased flood insurance with the expectation of increased flood frequency. Both groups shared the same anticipation that flood frequency will increase in the future, but the extent to which this could make a difference in the level of risk aversion and likelihood of purchasing flood insurance is not clear because the group mean difference is too marginal to make a difference.

The price of flood insurance premiums (FLPREM) was found to be a major factor in the decision to purchase flood insurance. The variable demonstrated strong discriminant power and emerged as third most significant $(\lambda=0.890$, $F=25.370, p<0.001)$ in contributing to the differentiation of the two groups on their propensity to purchase flood insurance. The basis of this difference may be seen in group mean score. Regarding this variable, the group of respondents who did not purchase flood insurance recorded a higher mean score (3.08) than the group that purchased flood insurance (2.45). The difference in group mean (0.63) was large enough to make a significant difference. The group that did not purchase flood insurance held the notion that the premium for flood insurance was expensive and was more unwilling to pay a slightly higher-than-fair price compared to those who had purchased flood insurance. Thus, GROUP 1 demonstrated more willingness to pay a slightly higher price to protect against loss, which also implies that they are more risk averse. The result is consistent with PT postulation that people, including modest-risk individuals, are willing to increase a premium somewhat higher than the fair price in order to pay for expected losses (Pashigian et al., 1966; Drèze, 1981; Cutler and Zeckhauser, 2004; Kunreuther and Pauly, 2006a; Sydnor, 2010; Ulrich, 2012). We also argue here that if the homeowners are willing to take additional risk by paying a premium that is more than actuarially fair and could exceed expected loss, then their decision to buy flood insurance may be influenced by loss aversion because they emphasise their expected loss more than their expected gains. This result is consistent with the findings of Smith (1968), MacDonald et al. (1987), Browne and Hoyt (2000), Dixon et al. (2006), 
Kunreuther et al. (1978), Palm (1981), Lamond et al. (2009), and Blanchard-Boehm et al. (2001).

The respondents' views about the insurance companies and how they affect the decision to purchase flood insurance or not were tested. Results show that there is a significant difference in their mean value with respect to the perception of unreliability of insurance firms to pay insurance claims and their reluctance to provide flood insurance coverage (V-INSREL) $(\lambda=0.963, F=7.856, p<0.01)$. Respondents who did not purchase insurance had a higher mean value (3.36) compared to those who purchased insurance (2.92). It could therefore be said that those who never purchased flood insurance felt that it was difficult to interest insurance companies in flood insurance coverage.

The roles of income level and education were also examined. The contribution on an income level (INCOML) in group differentiation was found to be significant $(\lambda=0.964$, $F=9.645, p<0.01$.) but the level of education (EDUCTN) was not $(\lambda=0.922, F=1.659, p>0.01)$. On an income level, examination of the group mean shows that the group that had purchased flood insurance registered a higher mean (1.83) compared to the group that had not (1.48). In other words, the propensity to purchase flood insurance increases significantly with income while education does not make a difference. While GROUP 1 registered higher income, which could increase the affordability of flood insurance, it is highly likely the group suffered greater losses of wealth (accumulated savings from income) from previous multiple high-impact flood experiences that foster their risk aversion. As Luigi and Paiella (2008) and Cameron and Shah (2011) pointed out, households that face income uncertainty or suffered loss of income from severe natural disaster exhibit a greater degree of risk aversion.

On the perception of the state of flood defence measures, there was a common opinion that the existing technical flood protection systems were not adequate (FLPROT). Hence the variable displayed poor discriminant power and did not contribute significantly in differentiating between the groups ( $\lambda=0.987, F=2.682, p>0.05)$. Though examining the group mean shows that GROUP 1 recorded a higher mean, the mean difference was too marginal to make a significant difference to flood insurance purchase or to the degree of risk aversion.

\section{Predicting discriminant function for group propensity to purchase flood insurance}

One of the objectives of this study is to build a model that includes only the most important predictive variables that best differentiate between a group of homeowners who purchased flood insurance and a group who did not as well as account for the group's degree of risk aversion. To this end, a stepwise method of enter/remove for deriving discriminant functions is most effective (Huberty, 1994). A discriminant function, also called a canonical root, is a latent variable that is a linear combination of discriminating (independent) variables. The stepwise method selects only variables that significantly contribute to discriminant function and predict group membership by selecting a variable that minimizes the overall Wilks' lambda at each step. As a result, all 11 variables were subjected to the stepwise method.

Table 2 shows that at 30 iterations and a 0.05 significant level, 5 out of the 11 variables entered the model in the following descending order of magnitude according to the stepwise model: number of flood experiences (V-NUMEXP); perceived high flood insurance premiums but willingness to pay slightly more than the fair price (V-FLPREM); perception of unreliability of insurance firms to pay insurance claims as well as their reluctance to provide flood insurance coverage (V-INSREL); distance of property from floodprone river (V-DISTFD); and income level (V-INCOML). Table 2 also provides statistics for verifying the significance of the discriminant function and identifying the variables that have the greatest impact and correlation with the discriminant function. The table reveals a canonical correlation $(\mathrm{CCr})$ of 0.507 , which implies that the function explained $42 \%$ $\left(\mathrm{CCr}^{2}\right)$ of variance in the group differences. However, when examining the function's Wilks' lambda $(\Lambda)$, the function is considered significant $(\Lambda=0.743, \chi 2(\mathrm{df}=5)=60.254$, $p<0.01$ ). Thus, we substantively infer that there is a significant discriminant function that clearly differentiates and separates the two groups of homeowners on the basis of the likelihood of their purchasing flood insurance as well as on the basis of flood risk aversion.

The table also displays the standardized discriminant function coefficients and structure matrix correlation used to assess each variable's unique contribution in terms of impact and correlation with the discriminant function. Consistent with ANOVA $(F)$ test, the standardized discriminant function coefficients (SCDFC) and structure matrix correlation (within group correlation) show that the variables that have the strongest impact and correlation with the discriminant function are "perception that flood insurance premiums are high but willing to pay a slightly higher-than-fair price to insure my house" $(\beta=0.452$ and within group correlation $=0.598)$; "number of high-impact floods experienced" $(\beta=$ 0.428 and within group correlation $=0.658$; "distance from flood-prone river" $(\beta=0.369$ and within group correlation $=0.611$; and "perception of unreliability of insurance firms to pay insurance claims as well as their reluctance to provide flood insurance coverage" $(\beta=0.325$ and within group correlation $=0.333$ ).

The classification result provides efficiency and predictive accuracy of the discriminant function. The model achieved a hit ratio of $80.2 \%$, indicating that $80.2 \%$ of the residential homeowners were correctly classified as either having flood insurance or not having flood insurance according to their flood risk aversion orientation. The achieved impressive hit ratio suggests that the model has practical significance in predicting demand-side factors distinguishing be- 
Table 2. Predictive model of flood insurance purchase. Variables entered/removed ${ }^{\mathrm{a}, \mathrm{b}, \mathrm{c}, \mathrm{d}}$.

\begin{tabular}{|c|c|c|c|c|c|c|c|c|c|}
\hline \multirow[t]{3}{*}{ Step } & \multirow[t]{3}{*}{ Entered } & \multicolumn{8}{|c|}{ Wilks' lambda } \\
\hline & & \multirow[t]{2}{*}{ Statistic } & \multirow[t]{2}{*}{ df1 } & \multirow[t]{2}{*}{ df 2} & \multirow[t]{2}{*}{ df3 } & \multicolumn{4}{|c|}{ Exact $\mathrm{F}$} \\
\hline & & & & & & Statistic & df1 & df2 & Sig. \\
\hline 1 & $\begin{array}{l}\text { Numbers of high-impact floods experienced } \\
\text { (V-NUMEXP) }\end{array}$ & 0.870 & 1 & 1 & 205 & 30.767 & 1 & 205 & 0.000 \\
\hline 2 & $\begin{array}{l}\text { Perception of high flood insurance premiums but } \\
\text { willing to pay slightly more than the fair price to in- } \\
\text { sure house (V-FLPREM) }\end{array}$ & 0.803 & 2 & 1 & 205 & 24.993 & 2 & 204 & 0.000 \\
\hline 3 & $\begin{array}{l}\text { Perception of unreliability of insurance firms to pay } \\
\text { insurance claims and their reluctance to provide flood } \\
\text { insurance coverage (V-INSREL) }\end{array}$ & 0.781 & 3 & 1 & 205 & 18.978 & 3 & 203 & 0.000 \\
\hline 4 & Distance from flood-prone river (V-DISTFD) & 0.760 & 4 & 1 & 205 & 15.955 & 4 & 202 & 0.000 \\
\hline 5 & Income level (V-INCOML) & 0.743 & 5 & 1 & 205 & 13.932 & 5 & 201 & 0.000 \\
\hline
\end{tabular}

\begin{tabular}{lccc}
\hline Standardized canonical discriminant function coefficients & & Structure matrix \\
\hline & Function 1 & Impact ranking & $\begin{array}{c}\text { (Within group } \\
\text { correlation) }\end{array}$ \\
\hline Number of high-impact floods experienced & -428 & 2 & -0.658 \\
\hline $\begin{array}{l}\text { Perception that flood insurance premiums are high but willing to } \\
\text { pay a slightly higher-than-fair price }\end{array}$ & 0.452 & 1 & 0.598 \\
\hline $\begin{array}{l}\text { Perception of unreliability of insurance firms to pay insurance claims } \\
\text { as well as their reluctance to provide flood insurance coverage }\end{array}$ & 0.325 & 4 & 0.333 \\
\hline Distance from flood-prone river & 0.369 & 3 & 0.611 \\
\hline Income level & -0.300 & 5 & -0.328 \\
\hline
\end{tabular}

\begin{tabular}{cr}
\hline Functions at group centroids & \\
\hline Has flood insurance & 0.423 \\
Has no flood insurance & -0.811 \\
\hline Model validation statistics & \\
\hline Canonical correlation (CCr) & 0.507 \\
CCr $^{2}$ ) & 0.4251 \\
Eigenvalue & $0.347^{\mathrm{a}}$ \\
Wilks' lambda & 0.743 \\
Chi-square (df =5) & 60.254 \\
Classification accuracy (hit ratio) & $80.2 \%$ \\
Sig & 0.000 \\
\hline
\end{tabular}

tween the group of respondents who purchased flood insurance and those who did not.

The study probed into the reasoning for not purchasing flood insurance. Figure 1 shows that $31 \%$ of respondents did not state any reason for not subscribing to flood insurance while $14 \%$ felt that it was not necessary. For these two categories it is difficult to explain their positions but suffice it to say they are either risk-neutral (indifferent) to risk of flooding and therefore unwilling to buy flood insurance or they underestimate the likelihood of a future flood risk. Flood insurance will not be attractive to individuals who think that a flood is not coming soon or perceive the loss as low. Camerer and Kunreuther (1989), Kunreuther (1996), Kunreuther and Paul (2006a), and Rees and Wambach (2008) argue that households will likely not buy flood insurance if they underestimate the probability of a flood's occurrence. $21.32 \%$ respondents noted that they did not purchase flood insurance because they were not living in a flood-prone area. This group may be living in an area of higher elevation and therefore see higher elevation as a substitute for flood insurance. They may be said to have a low degree of risk aversion because they perceive the probability of loss from a flood as very low. $16 \%$ did not have adequate knowledge about flood insurance, which is also a potential source of a low degree of 


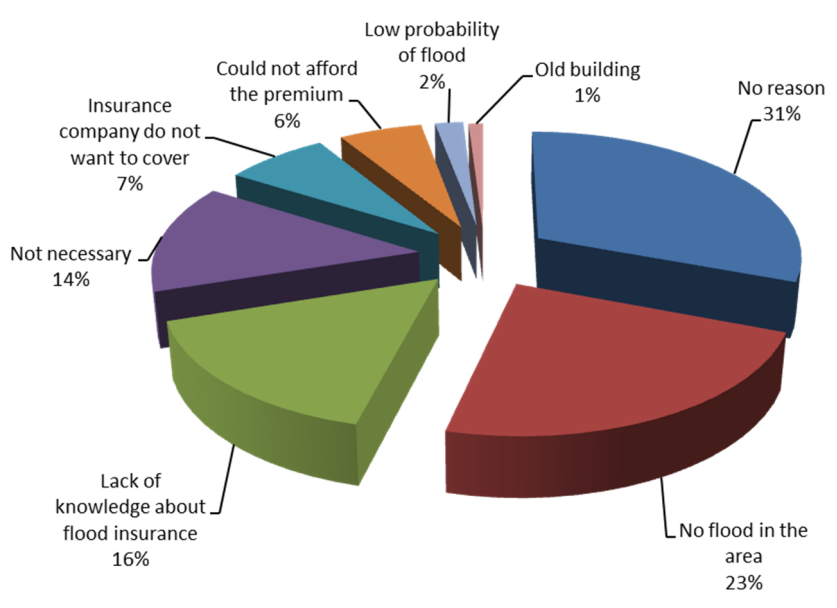

Figure 1. Reasons for not purchasing flood insurance.

risk aversion. This underscores the market failure to provide adequate information necessary for flood insurance purchase decisions. $7 \%$ stated the refusal of insurance companies to cover property as their main reason for not buying flood insurance. This category is risk averse and willing to pay a premium for property but is unable to get an insurance company to agree to provide the coverage. High premiums charged by insurance companies were a major reason for $6 \%$ of the respondents. This category is risk averse but, given their level of income or wealth, they were unwilling to buy an unfair insurance policy in which the premium was higher than the expected value of the claims should the adverse event (flood) occur. Some other reasons given by the respondents for not purchasing flood insurance, which could also account for low degree of risk aversion, include: low probability of experiencing a flood $(2 \%)$ and the perception that a building is too old $(1 \%)$.

\section{Conclusions}

The cardinal objective of this study is to determine the flood insurance penetration rate among residential homeowners in three districts of Johor, predict the variables that best differentiate between a group of homeowners who purchased flood insurance and a group who did not, based on their likelihood of purchasing flood insurance, and determine the groups' degrees of flood risk aversion. Our results revealed a $34 \%$ penetration rate, with Kota Tinggi having the highest penetration $(44 \%)$ and thus the highest degree of flood risk aversion. Overall we can say the flood insurance subscription rate is below average. The Wilks' lambda $F$ test for equality of group means, SCDFC, structure correlation, and canonical correlation have clearly shown that there are strong significant differences between the two groups of homeowners based on their objective flood risk exposure, subjective risks perception, and socio-economic cum demographic variables.
The most important variables distinguishing between those who did purchase flood insurance and those who did not were the following: the number of high-impact floods experienced; perception that a flood insurance premium is high but willingness to pay slightly more than the fair price; perception of unreliability of insurance firms to pay insurance claims as well as the reluctance of insurance firms to provide flood insurance coverage; distance from a flood-prone river; and income level. The variables constituted the dominant deciding anchors in the homeowners' decision to purchase or to not purchase flood insurance policy. Evidenced by the SCDFC, structure correlation shows that subjective risk perception measures (such as the number of high-impact floods experienced) were found to have more impact and, within the groups, more correlation with flood insurance decision and flood risk aversion than measures of objective flood risk exposure vis-à-vis the distance from a flood-prone river.

The research has some notable implications. The results showed the two groups have a convergence of opinion on the expectation of future increases in flood frequency and on the perception that existing technical flood protection systems are not adequate. Hence there is a common apprehension about the greater vulnerability of their property under the currently poor state of the flood defence systems and about the foreseeable increase in flood frequency. To reduce this apprehension it may be necessary to enhance the structural flood defence systems. Though some of the homeowners said they may drop flood insurance if they do not experience a flood for about 2 years, this may not lead to a substantial drop in flood insurance subscription. It was noted that $16 \%$ of the group of homeowners who did not purchase insurance indicated that they did not have adequate knowledge about flood insurance. Thus, we recommend a flood-risk awareness programme that includes a flood insurance promotion in flood-hit coastal areas. It was clear from our findings that unreliability of insurance firms in paying insurance claims as well as their reluctance to provide flood insurance coverage was a significant factor, accounting for the difference in flood insurance purchase. Specifically, $7 \%$ of the non-purchasing group stated the refusal of insurance companies to cover property as their main reason. Against this backdrop, there is a need for further investigation into reasons insurance firms are reluctant to provide flood insurance and examine ways to sensitize and incentivize them to provide coverage. Policies that compel insurance firms that provide flood insurance to redeem insurance claims will instil confidence among policy takers and also increase flood insurance subscription.

On the implications for theory, we conclude that in the light of the findings, it is pertinent to say that our results coincide more closely with PT than with EU theory. This is primarily because there is evidence that (a) the group of homeowners with insurance coverage demonstrated more willingness to pay a premium slightly higher than actuarially fair to protect against loss, which implies that their decision to purchase flood insurance is mainly influenced by loss 
aversion as they emphasize their expected loss more than expected gains; (b) decisions to purchase flood insurance are motivated by both objective risk exposure and subjective risk perceptions, with the latter having more influence; and (c) some homeowners that experienced a flood once or never experienced a flood purchased flood insurance, which supports PT contention that moderate- and small-size risk individuals could also voluntarily buy insurance. Nevertheless, there was a clear instance where the result holds for EU theory. About $6 \%$ of risk-averse EU maximizers were not willing to buy an unfair insurance coverage when the premium is higher than the expected value of the claims should the adverse flood event occur.

Edited by: P. Bubeck

Reviewed by: two anonymous referees

\section{References}

Badrul, H. A. S., Marzukhi, M. I., and Daud, A. R.: The worst flood in 100 yr: Johore experience, Commun. Health, 15, 1-14, 2010.

Baumann, D. D. and Sims, J. H.: Flood insurance: some determinants of adoption, Econ. Geogr., 54, 189-196, 1978.

BERNAMA: Malaysia Faces Serious Challenge in Handling Floods and Drought, available at: http://www.piam.org.my/index.php/news/, 21 June 2007.

Blanchard-Boehm, R. D., Berry, K. A., and Showalter, P. S.: Should flood insurance be mandatory? Insights in the wake of the 1997 New Year's Day flood in Reno-Sparks, Nevada, Appl. Geogr., 21, 199-221, 2001.

Botzen, W. J. W., Aerts, J. C. J. H., and van den Bergh, J. C. J. M.: Dependence of flood risk perceptions on socioeconomic and objective risk factors, Water Resour. Res., 45, W10440, doi:10.1029/2009WR007743, 2009.

Browne, M. J. and Hoyt, R. E.: The demand for flood insurance: empirical evidence, J. Risk Uncertainty, 20, 291-306, 2000.

Bubeck, P., Botzen, W. J. W., and Aerts, J. C. J. H.: A review of risk perceptions and other factors that influence flood mitigation behaviour, Risk Anal., 32, 1481-1495, 2012.

Burton, I. and Kates, R. W.: The Perception of natural hazards in resource management, Nat. Resour. J., 3, 412-441, 1964.

Business Times: Floods set to hit insurers with RM100m in claims, available at: http://www.piam.org.my/index. php/news/test-insurance-news/115-insurance-news/2007/

458-floods-set-tohit-insurers-with-rm100m-in-claims, 5 March 2007.

Camerer, C. F. and. Kunreuther, H.: Decision processes for low probability events: policy implications, J. Pol. Anal. Manage., 4, 565-592, 1989.

Cameron, L. and Shah, M.: Risk-taking behaviour in the wake of natural disasters risk aversion, Monash University of California, Irvin, CA, 2011.

Chan, N. W.: Increasing flood risk in Malaysia: causes and solutions, Disaster Prevent. Manage., 6, 72-86, 1997).

Chateauneuf, A. and Cohen, M.: Risk seeking with diminishing marginal utility in a non expected utility model, J. Risk Uncertainty, 9, 77-91, 1994.
Hasan, M. I. R. and Munirah, S. A.: A decision support system to deal with contemporary issues of climate change induced vulnerability and human security in Malaysia, Asian J. Environ. Disaster Manage. 3, 277-288, 2013.

Ho, J. C.: Coastal Flood Risk Assessment and Coastal Zone Management Case Study of Seberang Perai and Kuantan Pekan in Malaysia, Erasmus, Mundus Master's Thesis in Coastal and Marine Engineering and Management (CoMEM), University of Southamption, United Kingdom, 2009.

Cutler, D. M. and Zeckhauser, R.: Extending the theory to meet the practice of insurance, in: Brookings-Wharton Papers on Financial Services, edited by: Litan, R. E. and Herring, R., Brookings Institution, Washington, DC, 1-47, 2004.

Eckles, D. L. and Volkman Wise, J.: Prospect Theory and the Demand for Insurance, The Risk Theory Society, American Risk and Insurance Association (ARIA), Philadelphia, PA USA, available at: available at: http://www.aria.org/rts/proceedings/2012/ default.htm (last access: 18 September 2013), 2011.

Deloitte, K. C.: Institutional Study for DID - Final Report June 2003, Department of Irrigation and Drainage, Malaysia, 2003.

Desrosiers, M. A.: How individuals purchase insurance: going beyond expected utility theory casualty actuarial society, EForum, 2, 18 pp., available at: http://www.casact.org/pubs/ forum/12wforumpt2/Desrosiers.pdf, 2012.

Dixon, L., Clancy, N., Seabury, S. A., and Overton, A.: The National Flood Insurance Program's Market Penetration Rate, Estimates and Policy Implications, Rand Infrastructure, Safety, and Environment and Institute for Civil Justice, 2006.

Drèze, J. H.: Inferring risk tolerances from deductibles in insurance contracts, Geneva Pap. Risk Ins., 6, 48-52, 1981.

Dutta, D., Herath, S., and Musiake, K. A.: Mathematical model for flood loss estimation, J. Hydrol., 277, 24-49, 2003.

Eckles, D. L. and Volkman, J. W.: Prospect theory and the demand for insurance, The Risk Theory Society, American Risk and Insurance Association (ARIA), Philadelphia, PA, USA, available at: http://www.aria.org/rts/proceedings/2012/default.htm, 2011.

Epple, D. and Lave, L. B.: The role of insurance in managing natural hazard risks: private vs. Social decisions, Risk Anal., 8, 421-433, 1988.

FEMA: Mandatory purchase of flood insurance guidelines. Nevada policies, Federal Emergency Management Agency, FEMA (1997c), Washington, DC, 1997.

Gerrit, W.: Munich re urges climate action, Financial Times, available at: http://www.ft.com/intl/cms/s/0/ 98a3ac0a-f4e2-11de-9cba-00144feab49a, 2009.

Hair, J. F., Anderson Jr., R. E., and Tatham, L. R. L.: Multivariate Data Analysis with Readings, McMillan Publishing Company, New York, 1987.

Hamzah, J., Habibah, A., Buang, A., Jusoff, K., Toriman, M. E., Mohd Fuad, M. J., Er, A. C., and Azima, A. M.: Flood disaster, impacts and the tourism providers' responses - the Kota Tinggi experience, Adv. Nat. Appl. Sci., 6, 26-32, 2012.

Hershey, J. and Schoemaker, P.: Risk taking and problem context in the domain of losses: an unexpected utility analysis, J. Risk Ins., 47, 111-132, 1980.

Ho, J. C.: Coastal Flood Risk Assessment and Coastal Zone Management Case Study of Seberang Perai and Kuantan Pekan in Malaysia. Erasmus Mundus Master's Thesis in Insurance against Natural Disasters, Joseph Henry Press, Washington, DC, 2009. 
Huberty, C. J.: Applied Discriminant Analysis, Wiley and Sons, New York, 1994. InsuranceInfo: available at: http://www.insuranceinfo.com.my/_system/media/ downloadables/houseowner_insurance.pdf, 2011.

Intergovernmental Panel on Climate Change (IPCC): Fourth Assessment Report: Climate Change 2007, Contribution of Working Group II, Cambridge University Press, Cambridge, UK, 2007.

Isenberg, D.: How senior managers think, in: Decision Making, edited by: Bell, D., Raiffa, H., and Tversky, A., 525-539, 1989.

Johnson, W. K.: Physical and Economic feasibility of Nonstructural Flood Plain Management measures, US Army Corps of Engineers, 1978.

Kahneman, D. and Tversky, A.: Prospect theory: an analysis of decision under risk, Econometrica, 47, 263-292, 1979.

Keizrul, A.: Floods in Malaysia, available at: http://www. icharm.pwri.go.jp/publication/jan_20_22_2004_ws/pdf_output/ abdullah.pdf (last access: 13 June 2012), 2004.

Kreibich, H., Thieken, A. H., Petrow, Th., Müller, M., and Merz, B.: Flood loss reduction of private households due to building precautionary measures - lessons learned from the Elbe flood in August 2002, Nat. Hazards Earth Syst. Sci., 5, 117-126, doi:10.5194/nhess-5-117-2005, 2005.

Kreibich, H., Christenberger, S., and Schwarze, R.: Economic motivation of households to undertake private precautionary measures against floods, Nat. Hazards Earth Syst. Sci., 11, 309-321, doi:10.5194/nhess-11-309-2011, 2011.

Kriesel, W. and Landry, C.: Modeling the decision to buy flood insurance: an empirical analysis for coastal Areas, Paper presented at the American Agricultural Economics Association Annual Meeting in Orlando, Florida, July 2000.

Kriesel, W. and Landry, C.: Participation in the National Flood Insurance Program: an empirical analysis for coastal properties, J. Risk Ins., 71, 405-420, 2004.

Kunreuther, H. C.: Even Noah built an ark, The Wharton Magazine, summer, 28-35, 1978.

Kunreuther, H. C.: Mitigating disaster losses through insurance, J. Risk Uncertainty, 12, 171-187, 1996.

Kunreuther, H. and Pauly, M.: Insurance decision making and market behaviour, Found. Trend. Microeconom., 1, 63-127, 2005.

Kunreuther, H. and Pauly, M.: Insurance Decision-Making and Market Behaviour, Now Publishers Inc, Hanover, MA, 2006a.

Kunreuther, H. and Pauly, M.: Rules rather than discretion: lessons from hurricane Katrina, J. Risk Uncertainty, 33, 101-116, $2006 \mathrm{~b}$.

Kunreuther, H. and Roth Sr., R. J. (Eds.): Paying the Price: The Status and Role of Insurance against Natural Disasters. Washington, DC, Joseph Henry Press, 1998.

Kunreuther, H. C. and White, G. F.: Flood hazard delineation: the one percent standard, Water Resour. Update, 95, 31-35, 1994.

Kunreuther, H., Ginsberg, R., Miller, L., Sagi, P., Slovic, P., Borkan, B., and Katz, N.: Disaster Insurance Protection: Public Policy Lessons, Wiley, New York, 1978.

Lamond, J., Proverbs, D., and Hammond, F.: Flooding and Property Values - Findings in Built and Rural Environment, Royal Institute of Chartered Surveyors, London, 2009.

Landry, C. E. and Jahan-Parvar M. R.: Flood insurance coverage in the coastal zone, J. Risk Insur., 2, 361-388, 2011.
Levin, J.:Choice under uncertainty, available at: http://web. stanford.edu/ jdlevin/Econ\%20202/Uncertainty.pdf (last access: 18 September, 2013), 2006.

Liu, P. S. and Chan, N. W.: The Malaysian flood hazard management program, Int. J. Emergency Manage., 1, 205-214, 2003.

Luigi, G. and Monica Paiella, M.: Risk aversion, wealth, and background risk, J. Eur. Econ. Assoc., 6, 1109-1150, 2008.

MacDonald, D. N., Murdoch, 5 J. C., and White, H. L.: Uncertain hazards, insurance, and consumer choice: evidence from housing markets, Land Econ., 63, 361-371, 1987.

March, J. and Shapira, Z.: Managerial perspectives on risk and risk taking, Manage. Sci., 33, 1404 1416, 1987.

McPherson, H. J. and Saarinen, T. F.: Flood plain dwellers' perception of the flood hazard in Tucson, Arizona, Ann. Regional Sci., 11, 25-40, 1977.

Merz, B.: Hochwasserrisiken: Grenzen und Möglichkeiten der Risikoabschätzung, Schweizerbart, Stuttgart, 2006.

MNREM (Ministry of Natural Resources and Environment Malaysia): Flood and Drought Management in Malaysia, available at: http://www.met.gov.my/files/ClimateChange2007/ session1b/K2\%20Husaini_P.doc (last access: 22 May 2012), 2007.

Ndubisi, N. O.: Socio-environmental marketing in developing nations: a comparison of African and Asian businesses, J. Asian Afr. Stud., 43, 251-277, 2008.

Ndubisi, N. O.: Factorial and discriminant analyses of environmental sensitivity and initiative of Nigerian firms, Thunderbird Int. Business Rev., 53, 19-35, 2011.

Palm, R. I.: Real Estate Agents and Special Studies Zones Disclosure: the Response of California Home Buyers to Earthquake Hazard Information, Monograph No. 32, University of Colorado, Institute of Behavioural Science, Hazards Research and Information Application Centre, Boulder, CO, 1981.

Pashigian, B. P., Schkade, L. L., and Menefee, G. H.: The selection of an optimal deductible for a given insurance policy, J. Bus., 39, 35-44, 1966.

Plate, E. J.: Flood risk and flood management, J. Hydrol., 267, 2-11, 2002.

Rabin, M.: Risk Aversion, Diminishing Marginal Utility, and Expected-Utility Theory: a Calibration Theorem, 1997.

Rabin, M.: Diminishing marginal utility of wealth cannot explain risk aversion, in: Choices, Values, and Frames, edited by: Kahneman, D. and Tversky, A, Russell Sage Foundation, Cambridge University Press, Cambridge, UK, 202-208, 2000a.

Rabin, M.: Risk aversion and expected utility theory: a calibration theorem, Econometrica, 68, 1281-1292, 2000b.

Rees, R. and Wambach, A.: The microeconomics of insurance, Found. Trend. Microeconom., 1-2, 1-163, 2008.

Sebora, T. C.: Expected utility theory vs. prospect theory: implications for strategic decision makers, J. Managerial Issues, 7, 4161, 1995.

Singh, P.: Floods set to hit insurers with RM100m in claims, New Straits Times, available at: http://www.highbeam.com/doc/ 1P1-135651064.html, 2007.

Slovic, P.: Perception of risk, Science, 236, 280-285, doi:10.1126/science.3563507, 1987.

Smith, V. L.: Optimal insurance coverage, J. Polit. Econ., 76, 68-77, 1968. 
Stern, N.: The Economics of Climate Change: the Stern Review, Cambridge University Press, Cambridge, UK, 2006.

Stern, N.: The economics of climate change, Am. Econ. Rev., 98, 1-37, 2008.

Sydnor, J.: Over insuring modest risks, Appl. Econ., 2, 177-199, 2010.

Tversky, A. and Kahneman, D.: The framing of decisions and the psychology of choice, Science, 211, 453-458, 1981.
Tversky, A. and Kahneman, D.: Advances in prospect theory: cumulative representation of uncertainty, J. Risk Uncertainty, 5, 297323, 1992.

Ulrich, S.: Insurance Demand under Prospect Theory: a Graphical Analysis, Working Paper No. 1764, Kiel Institute for the World Economy, Hindenburgufer, Germany, 2012.

World Meteorological Organization (WMO): Social Aspects and Stakeholder Involvement in Integrated Flood Management, Geneva, Switzerland, 2. 